JKKP : Jurnal Kesejahteraan Keluarga dan Pendidikan

http://doi.org/10.21009/JKKP

DOI: doi.org/10.21009/JKKP.011.07

E-ISSN : 2597-4521

\title{
PERBEDAAN POLA PENGASUHAN ANAK BERDASARKAN TINGKAT PENDAPATAN KELUARGA
}

\author{
Fitri Kamaliah ${ }^{1}$, Melly Prabawati ${ }^{2}$, Rusilanti ${ }^{3, a}$ \\ Email : $\underline{\text { rusilanti@gmail.com }}^{\mathbf{a}}$ \\ 1,2,3 Jurusan IImu Kesejahteraan Keluarga \\ Fakultas Teknik, Universitas Negeri Jakarta
}

\begin{abstract}
Abstrak
Penelitian bertujuan untuk mengetahui perbedaan pola pengasuhan anak berdasarkan tingkat pendapatan keluarga. Penelitian ini dilihat dari sosial ekonomi yang dipilih berdasarkan tingkat pendapatan orang tua dan pola asuh dibatasi pada perkembangan anak usia 2-5 tahun. Penelitian dilaksanakan di Kelurahan Karawaci Baru, Kecamatan Karawaci Kota Tangerang. Penelitian terhitung sejak bulan Oktober sampai dengan bulan Juni 2014. Metode Penelitian yang digunakan adalah metode survei. Populasi dalam penelitian ini seluruh ibu rumah tangga yang memiliki anak usia balita. Teknik pengambilan sampel dalam penelitian ini akan dilakukan apabila populasi dianggap homogen dan sampel diambil sebanyak 82 orang dengan menggunakan teknik Proportionate Random Sampling. Teknik analisis data yang digunakan adalah uji normalitas dengan menggunakan rumus chi-kuadrat untuk mengetahui data pola pengasuhan pada tingkat pendapatan adalah berdistribusi normal. Untuk perhitungan uji $F$ data berdistribusi normal dan homogen. Hasil Uji Hipotesis dengan menggunakan rumus One Way Anova dan uji t-test. Hasil tersebut dapat disimpulkan maka $\mathrm{HO}$ diterima sehingga tidak terdapat perbedaan pola pengasuhan anak balita berdasarkan tingkat pendapatan keluarga.
\end{abstract}

Kata Kunci: Pola Asuh Orang Tua, Pola Pengasuhan Anak, Pendapatan Keluarga.

\section{Differences in Parenting Style Based on Family Income}

\begin{abstract}
The study aims to determine differences parenting by family income level. This study of the socio-economic views are selected based on the level of income and parenting on the development of children aged 2-5 years. The experiment was conducted at the New Village Karawaci, District Karawaci Tangerang City. Research starting from October until J une 2014. Methods used is survey method. The population of this research is housewives and children with age under five population. In this study sampling technique will be carried out if the population is homogeneous and the sample taken as many as 82 people using proportionate random sampling technique. The data analysis technique is used the normality test using the chi-square, it means that the parenting data is on income levels are normally distributed. The calculation of data $F$ test were normally distributed and homogeneous. Hypothesis Test results using the formula One Way ANOVA and t-test. We
\end{abstract}


can conclude these results that $\mathrm{HO}$ is accepted that there are differences in parenting toddlers is based on family income levels.

Keywords: parenting parents, patterns of child care, family income.

\section{PENDAHULUAN}

Kesejahteraan sosial ekonomi merupakan suatu kondisi dan tata kehidupan sosial ekonomi yang sejahtera, yaitu yang memungkinkan setiap orang, kelompok atau masyarakat untuk memenuhi kebutuhan jasmaniah dan rohaniah yang dikenal sebagai dasar manusia dengan sebaik-baiknya (Siswanta, 2008:23). Permasalahan ekonomi dalam keluarga merupakan masalah yang sering dihadapi. Tanpa disadari bahwa permasalahan ekonomi dalam keluarga akan berdampak pada anak (Soedarmono, 2000:17). Keluarga merupakan lingkungan pendidikan pertama untuk anak, keluarga sebagai pembentukan awal perkembangan untuk anak dan dari keluarga pola berfikir, bersikap dan karakteristik anak terbentuk. Keluarga yang baik adalah keluarga yang saling menyayangi satu sama lain terhadap sesama anggota keluarganya.

Pemerintah Indonesia terdorong untuk menyusun program yang terkait dengan pengasuhan, pendidikan dan pengembangan anak usia dini. Sebagai wujud nyata komitmen pemerintah maka ditetapkannya kebijakan dasar Program Nasional Bagi Anak Indonesia (PNBAI) sampai 2015,yang isinya sebagai berikut; 1) mewujudkan anak yang sehat, tumbuh dan berkembang secara optimal melalui pemberdayaan masyarakat, peningkatan kerja sama sektoral, perbaikan lingkungan peningkatan kualitas serta jangkauan upaya kesehatan, peningkatan sumber daya, pembiayaan dan managemen kesehatan, serta pengembangan ilmu pengetahuan dan tehnologi; 2) mewujudkan anak yang cerdas ceria dan berakhlak mulia melalui upaya perluasan aksesibilitas, peningkatan kualitas dan efisiensi pendidikan serta partisipasi masyarakat; 3) mewujudkan perlindungan dan partisipasi aktif anak melalui perbaikan mutu pranata sosial dan hukum, penelitian pemerataan dan perluasan jangkauan penelitian pelayanan terutama bagi anak yang berada dalam keadaan darurat dalam jaringan kerja nasional dan internasional (Jalal, 2005:16).

Pola asuh orang tua secara harfiah mempunyai maksud pola interaksi antara orangtua dan anak. Pola interaksi ini meliputi, bagaimana sikap atau perilaku orangtua saat berhubungan dengan anak (Lidyasari, 2010:16). Berdasarkan uraian tokoh di atas dapat diketahui bahwa tingkat pendapatan keluarga memiliki pengaruh yang besar terhadap pola pengasuhan salah satunya yaitu perilaku anak. Perilaku anak dapat dilihat dari bagaimana orangtua mengasuh atau memberikan pola pengasuhan kepada anak tersebut. Pengaruh pola asuh orangtua dengan tingkat ekonomi menengah keatas dan menengah kebawah sangatlah berbeda.

Pada latar belakang tersebut timbul beberapa identifikasi permasalahan yaitu; 1) Apakah tingkat pendapatan orangtua mempengaruhi pola pengasuhan anak?; 2) Bagaimana orangtua menjalankan pola pengasuhan pada anak?; 3) Bagaimana menerapkan pola pengasuhan anak berdasarkan tingkat pendapatan keluarga?

Berdasarkan latar belakang, identifikasi, dan pembatasan masalah rumusan masalah pada penelitian ini adalah: "apakah terdapat perbedaan pola pengasuhan anak berdasarkan tingkat pendapatan keluarga". Tujuan dari penelitian ini adalah untuk mengetahui perbedaan pola asuh anak berdasarkan tingkat pendapatan keluarga dan untuk mengetahui bagaimana orang tua menerapkan pola pengasuhan pada anak berdasarkan tingkat pendapatan keluarga.

Pendapatan dalam satu keluarga akan mempengaruhi aktivitas keluarga dalam pemenuhan kebutuhan keluarga. Keadaan ekonomi keluarga berperan dalam perkembangan anak dan menentukan tingkat kesejahteraan keluarga. Dengan adanya perekonomian yang cukup dalam keluarga, lingkungan 
materi yang dihadap anak akan lebih luas serta memiliki kesempatan untuk mengembangkan macammacam kecakapan, (Sajogyo dalam Paputungan, 2009:30). Keluarga adalah sekolah pertama bagi seorang anak, disini mereka mendapatkan pendidikan pertama kali, orang tua sebagai lingkungan yang dikenal anak pertama kali akan mempengaruhi proses perkembangan anak. orang tua sebagai pengasuh anak berperan dalam meletakkan dasar-dasar kepribadian anak, karena orang tua merupakan pendidik pembimbing, dan pelindung bagi anak, Djuwarijah (Muryono, 2009:113).

Pendapatan keluarga adalah penghasilan dari hasil kerja seseorang. Pendapatan keluarga tersebut mempengaruhi adanya kebutuhan ekonomi keluarga tersebut. Seseorang yang sudah menikah dan berkeluarga, tentu kebutuhan ekonomi keluarganya menjadi bertambah, dan hal ini sangat berpengaruh jika keluarga ini memiliki anak. karena pendidikan anak dan kebutuhan hidup sehai-hari keluarga tersebut tentunya mengalami peningkatan. Oleh karena itu, untuk memperoleh hasil yang seimbang, maka tingkat pendapatan keluarga perlu di damping oleh pengeluaran yang seimbang dan tidak berlebihan hal ini perlu diterapkan agar keluarga mencapai kesejahteraan hidup. Pendapatan keluarga adalah seluruh penghasilan yang diperoleh dari semua anggota keluarga yang bekerja.

Menurut Rianto Adi (2004:40) tingkat pendapatan ekonomi digolongkan menjadi tiga dimensi, dapat dilihat pada tabel 2.1, yaitu:

Tabel 1. Tingkat Ekonomi (dalam Rupiah)

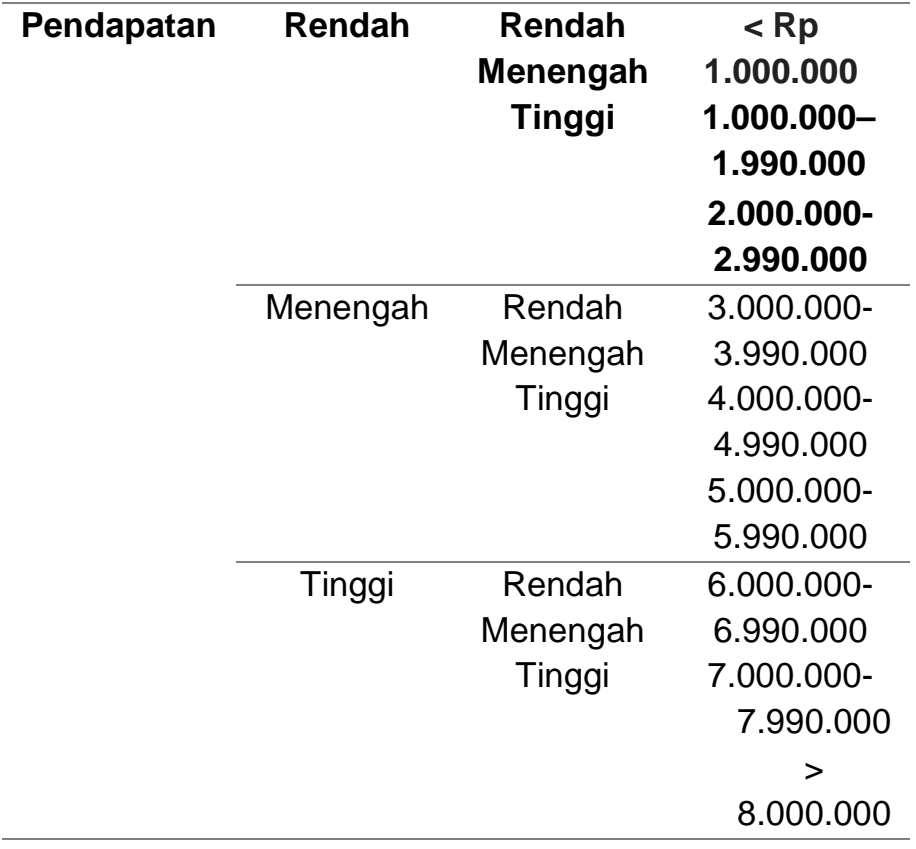

Pola asuh orang tua merupakan interaksi antara anak dan orang tua selama mengadakan pengasuhan kegiatan pengasuhan, seperti mendidik, membimbing dan mendisiplinkan serta melindungi anak untuk mencapai kedewasaan sesuai dengan norma-norma yang ada dalam masyarakat (Tarmudji, 2002:26). pola asuh adalah semua interaksi antara orang tua dengan anak. Interaksi disini termasuk ekspresi sikap, nilai, perhatian dalam membimbing, mengurus dan melatih perilaku anak. Dalam kegiatan memberikan pengasuhan, orangtua akan memberikan perhatian, peraturan, disiplin, hadiah dan hukuman, serta tanggapan terhadap keinginan anaknya. Sikap, perilaku, dan kebiasaan orangtua selalu dilihat, dinilai, dan ditiru oleh anaknya yang kemudian semua itu secara sadar atau tidak sadar akan diresapi kemudian menjadi kebiasaan pula bagi anakanaknya. 
Dimensi pola asuh orang tua terbagi menjadi 4 macam, yaitu; 1) Kontrol, kontrol merupakan sikap saat orang tua dapat menerima prilaku dan tingkah laku anak yang tidak sesuai dengan harapan orang tua; 2)Tingkah laku, dimana pada tingkah laku, orang tua mampu mendorong kemandirian anak dan mengajarkan anak untuk bertanggung jawab atas segala tindakan anak; 3) Komunikasi, adanya komunikasi verbal, baik komunikasi dua arah yaitu orang tua dan anak, atau komunikasi satu arah hanya orang tua saja; 4) Kasih sayang, adanya kehangatan, cinta dan perawatan dari orang tua untuk anak, sehingga anak merasa nyaman dan aman ketika mereka ada disamping orang tua.

Gaya pengasuhan orang tua terbagi menjadi empat macam menurut Baumrind (Santrock, 2011:102), diantaranya yaitu: 1) Pengasuhan Otoriter (authoritarian parenting) adalah gaya membatasi dan menghukum ketika orang tua memaksakan anak untuk mengikuti arahan mereka dan menghormati pekerjaan serta upaya mereka. Orang tua otoriter menempatkan batasan-batasan dan kontrol yang tegas pada anak serta memungkinkan sedikit pertukaran verbal; 2) Pengasuhan Otoritatif (authoritative parenting) adalah gaya pengasuhan ketika orang tua mendorong anakanak untuk menjadi mandiri, tetapi masih menempatkan batasan dan control atas tindakan mereka; 3) Pengasuhan Permisif (indulgent parenting) merupakan sebuah gaya pengasuhan ketika orang tua sangat terlibat dengan anak-anak mereka, tetapi menempatkan beberapa tuntutan atau control atas mereka; 4) Pengasuhan Lalai (neglectful parenting) merupakan gaya ketika orang tua sangat tidak terlibat dalam kehidupan anak.

Pola pengasuhan anak adalah kemampuan keluarga dan masyarakat untuk menyediakan waktu, perhatian, dan dukungan terhadap anak agar dapat tumbuh dan berkembang sebaikbaiknya secara fisik, mental, dan sosial. Bentuk kongkrit pola pengasuhan anak berupa sikap dan perilaku ibu atau pengasuh lain dalam hal kedekatannya dengan anak, memberikan makan, merawat, menjaga kebersihan, memberikan kasih sayang, dan sebagainya (Ernawati, 2006:41). Pola pengasuhan anak yaitu penerapan gaya pengasuhan yang dilakukan oleh setiap orang tua terhadap anaknya. Anak-anak perlu pengasuhan yang baik, lembut, penuh perhatian, dan kasih sayang terhadap kedua orang tua nya. Karena, setiap anak berhak memperoleh kasih sayang dari kedua orang tua nya. Pengasuhan juga berhubungan dengan kesehatan, gaya hidup anak, pola makan, pola asuh belajar, dan lain sebaginya.

Lingkungan pengasuhan anak usia 2-5 tahun dalam keluarga yang terlihat dari pola pengasuhan yang diberikan merupakan seluruh interaksi antara subjek dan objek berupa bimbingan, pengarahan dan pengawasan terhadap aktifitas objek sehari-hari yang berlangsung secara rutin, membentuk suatu pola dan merupakan usaha yang diarahkan untuk mengubah tingkah laku sesuai dengan keinginan pendidik atau pengasuh (Gunarsa, 2003:61). Lingkungan pengasuhan anak ialah, cara mendidik dan menjadikan anak sebagai sahabat dari orang tua. Dengan begitu, output nya ialah, anak tersebut akan lahir sebagai anak yang selalu mengasihi teman-temannya.

Terdapat enam ciri yang dibutuhkan untuk melakukan pengasuhan dengan baik, yaitu: (1) hubungan kasih sayang; (2) kelekatan atau keeratan hubungan; (3) hubungan yang tidak terputus; (4) interaksi yang memberikan rangsangan; (5) hubungan dengan satu orang; (6) melakukan pengasuhan anak dirumah sendiri. Dalam keenam ciri tersebut kasih sayang merupakan unsur yang penting sekali dalam hubungan yang terjalin antara keluarga yang berkembang menjadi kelekatan anak terhadap orang tua. (Paputungan, 2009:40). Terdapat tiga macam perkembangan yang dapat mempengaruhi perkembangan anak usia 2-5 tahun, yaitu: 1) Perkembangan psikomotor atau fisik merupakan dasar bagi kemajuan perkembangan berikutnya. Dengan meningkatnya pertumbuhan tubuh, baik menyangkut ukuran berat dan tinggi, maupun kekuatannya memungkinkan anak untuk dapat lebih mengembangkan keterampilan fisiknya, dan eksplorasi terhadap lingkungannya dengan bantuan dari orangtuanya. Perkembangan fisik anak ditandai juga dengan berkembangnya kemampuan atau keterampilan motorik, baik yang kasar maupun yang lembut (Yusuf, 2011:164); 2) Kecerdasan atau perkembangan kognitif anak pada usia 2-5 tahun kecerdasan majemuk sudah tampak pada usia ini, Jean Piaget (Yusuf, 2011:163): 3) Perkembangan Psikososial, yaitu Perkembangan sosial anak sangat dipengaruhi oleh iklim sosio-psikologis keluarganya (Yusuf, 2011:163).

Jurnal Kesejahteraan Keluarga dan Pendidikan [JKKP] Vol.01 No.01 doi.org/10.21009/JKKP.011.07 


\section{METODE PENELITIAN}

Penelitian ini dilaksanakan di wilayah Kelurahan Karawaci Baru, Kecamatan Karawaci, Kota Tangerang. Waktu penelitian dilaksanakan selama 9 bulan, dimulai pada bulan Oktober sampai dengan bulan Juli 2014.

Metode Survey digunakan untuk menentukan perbedaan pola pengasuhan anak berdasarkan tingkat pendapatan keluarga. Desain penelitian yang di gunakan dalam penelitian ini adalah desain penelitian dengan data Primer dan Sekunder. Sebagian besar dari tujuan desain ini desain penelitian adalah untuk memperoleh data yang relevan, dapat dipercaya, dan valid.

Populasi penelitian ini dipilih pada Seluruh anggota Posyandu yang berada di wilayah Kelurahan Karawaci Baru, Kota Tangerang. Jumlah populasi di Posyandu Kelurahan Karawaci Baru berjumlah 576 orang. Sampel dalam penelitian ini adalah Ibu Rumah tangga yang memiliki karakteristik yaitu balita usia 2-5 tahun dan untuk mengetahui kelompok

pendapatan dari setiap keluarga, diberikan kisikisi instrument berupa identitas keluarga yang disertai dengan penghasilan tetap perbulan dan penghasilan tambahan perbulan.

Teknik pengambilan sampel pada penelitian ini yaitu Proportionate Random Sampling Teknik ini digunakan bila populasi mempunyai anggota/unsur yang tidak homogen dan berstrata secara proporsional (Sugiyono, 2008:82), sampel pada penelitian ini berjumlah 82 orang.

\section{HASIL DAN PEMBAHASAN}

Deskripsi data akan dipaparkan dalam 3 bagian yaitu pola pengasuhan anak berdasarkan tingkat pendapatan tinggi, menengah, dan rendah. 1) Pengasuhan Anak Berdasarkan Tingkat Pendapatan Keluarga;

\section{Gaya pengasuhan berdasarkan tingkat pendapatan tinggi.}

Dapat dijelaskan bahwa skor 120-160 adalah kriteria pola pengasuhan otoritatif, 80120 pengasuhan otoriter, 40-80 pengasuhan permissif, dan skor 0-40 pengasuhan lalai. Pada rentang skor pengasuhan di tingkat pendapatan tinggi adalah 101-135, terdapat 18 orang yang memiliki kriteria skor 120-133 dengan presentase $69,23 \%$ artinya, terdapat 18 orang yang menerapkan pengasuhan otoritatif sedangkan terdapat 8 orang yang memiliki kriteria skor pengasuhan $100-119$ dengan presentase $30,77 \%$ artinya, hanya 8 orang yang menerapkan pengasuhan otoriter berdasarkan tingkat pendapatan keluarga. Untuk meleangkapi perhitungan tersebut, dapat dilihat tabel 2:

Tabel 2. Skor Gaya Pengasuhan Anak berdasarkan Tingkat Pendapatan Tinggi

\begin{tabular}{lll}
\hline Pengasuhan & Skor & Jumal \\
\hline Otoritatif & $120-160$ & 18 \\
Otoriter & $80-120$ & 8 \\
Permisif & $40-80$ & 0 \\
Lalai & $0-40$ & 0 \\
\hline Total & & 26 \\
\hline
\end{tabular}

\section{Gaya Pengasuhan Anak Berdasarkan Tingkat Pendapatan Menengah.}

Pada rentang skor pengasuhan di tingkat pendapatan menengah adalah 101-135, terdapat 21 orang yang memiliki kriteria skor $120-133$ dengan presentase $70 \%$ artinya, terdapat 21 orang yang menerapkan pengasuhan otoritatif sedangkan terdapat 9 orang yang memiliki kriteria skor pengasuhan 100-119 dengan 
presentase $30 \%$ artinya, hanya 9 orang yang menerapkan pengasuhan otoriter berdasarkan tingkat pendapatan keluarga. Untuk melengkapi perhitungan tersebut, dapat dilihat tabel 3:

Tabel 3. Skor Gaya Pengasuhan Anak berdasarkan Tingkat Pendapatan Menengah

\begin{tabular}{ccc}
\hline Pengasuhan & Skor & Jumal \\
\hline Otoritatif & $120-160$ & 21 \\
Otoriter & $80-120$ & 9 \\
Permisif & $40-80$ & 0 \\
Lalai & $0-40$ & 0 \\
\hline Total & & 30 \\
\hline
\end{tabular}

\section{Gaya Pengasuhan Anak Berdasarkan Tingkat Pendapatan Rendah.}

Pada rentang skor pengasuhan di tingkat pendapatan rendah adalah 106-135, terdapat 17 orang yang memiliki kriteria skor 120-133 dengan presentase 65,38\% artinya, terdapat 17 orang yang menerapkan pengasuhan otoritatif sedangkan terdapat 9 orang yang memiliki kriteria skor pengasuhan 100-119 dengan presentase $34,61 \%$ artinya, hanya 9 orang yang menerapkan pengasuhan otoriter berdasarkan tingkat pendapatan keluarga. Untuk melengkapi perhitungan tersebut, dapat dilihat tabel 4:

Tabel 4. Skor Gaya Pengasuhan Anak berdasarkan Tingkat Pendapatan Rendah

\begin{tabular}{ccc}
\hline Pengasuhan & Skor & Jumal \\
\hline Otoritatif & $120-160$ & 17 \\
Otoriter & $80-120$ & 9 \\
Permisif & $40-80$ & 0 \\
Lalai & $0-40$ & 0 \\
\hline Total & & 26 \\
\hline
\end{tabular}

\section{Dimensi Pola Asuh berdasarkan Tingkat Pendapatan Keluarga.}

Terdapat tiga dimensi pendapatan keluarga yang terdiri dari tingkat pendapatan tinggi, menengah dan rendah, dan terdapat tiga dimensi pola asuh yaitu kontrol, tingkah laku, komunikasi dan kasih sayang. Dimensi pola asuh berdasarkan tingkat pendapatan tinggi, menengah dan rendah memiliki presentase yang beragam, dan dimensi tingkah laku adalah dimensi paling dominan dengan presentase paling tertinggi yaitu $32,7 \%$. Dengan demikian, dalam perhitungan dimensi pola asuh berdasarkan tingkat pendapatan keluarga, dimensi tingkah laku adalah dimensi yang sangat di minati oleh orang tua dalam memberikan bimbingan berupa dorongan kepada anak agar anak menjadi pribadi yang mandiri.

Berdasarkan hasil rata-rata hitung skor variabel pengasuhan anak pada dimensi kontrol memiliki presentase $71,95 \%$, dimensi tingkah laku memiliki presentase $75,25 \%$, dimensi komunikasi memiliki presentase $79,35 \%$, dan dimensi kasih sayang memiliki persentase sebesar 71,06\%. Dimensi komunikasi dapat terlihat dari adanya sikap orang tua yang selalu menciptakan komunikasi verbal dengan anak, serta keterlibatan oraang tua terhadap perasaan dan pendapat anak.

Berdasarkan perhitungan presentase pengasuhan anak berdasarkan tingkat pendapatan keluarga, dapat dilihat bahwa, pada tingkat pendapatan tinggi, pengasuhan lalai memiliki presentase dominan yaitu $26,9 \%$. Sedangkan presentase pada tingkat pendapatan menengah dan rendah, memiliki presentase yang hampir sama, yaitu dominan pada pengasuhan otoritatif dengan nilai presentase $27,6 \%$ hingga $27,9 \%$. 
Analisis statistika untuk membuktikan masing-masing kelompok tidak terdapat perbedaan, maka digunakan rumus $\mathrm{Uji}$-T, dengan syarat thitung $\leq$ tabel. Hasil perhitungan yaitu pada tingkat pendapatan tinggimenengah thitung $\leq$ tabel $(-0,466 \leq 2,005)$ tingkat pendapatan tinggi-rendah $(-0,216 \leq 2,009)$ dan pada tingkat pendapatan menengah-rendah $(0,274 \leq 2,005)$. Hasilnya menunjukan bahwa tidak terdapat perbedaan pengasuhan anak berdasarkan tingkat pendapatan keluarga.

Hasil analisis menunjukkan bahwa penelitian ini telah berhasil namun tidak dapat menguji kebenaran hipotesis yaitu terdapat perbedaan pola pengasuhan anak berdasarkan tingkat pendapatan keluarga, tetapi hasil penilitian ini menyatakan bahwa tidak terdapat perbedaan pola pengasuhan anak berdasarkan tingkat pendapatan keluarga. Dari perhitungan, diperoleh data rata-rata pola pengasuhan anak usia balita yang diterapkan oleh orang tua adalah otoritatif. Tidak terdapat perbedaan pola pengasuhan anak berdasarkan pendapatan, ketiga nya mengacu pada pengasuhan otoritatif.

Pemilihan dimensi pola asuh merupakan faktor penting dalam keberhasilan penilaian gaya pengasuhan ini. Dengan tidak terdapat perbedaan pada penelitian ini, namun pengasuhan otoritatif adalah salah satu gaya pengasuhan terbaik bagi orang tua terhadap anak, khusus nya anak usia balita.

Keluarga yang berpendapatan tinggi memiliki kemampuan yang menunjang untuk tercapainya lingkungan pengasuhan yang baik untuk anak-anaknya, seperti konsumsi dan pola makan anak untuk memperoleh gizi yang baik, tempat tinggal yang nyaman dan aman untuk proses pertumbuhan dan perkembangan anak, ketersediannya alat-alat permainan untuk anak, dan lain sebagainya. Sedangkan keluarga yang berpendapatan rendah memiliki keterbatasan untuk menunjang kehidupan keluarga dan anakanaknya. Lain hal nya dengan keluarga yang berpendapatan menengah, mereka mampu mencukupi kebutuhan lingkungan pengasuhan anak-anaknya serta keluarga, karena mereka tergolong keluarga yang berkebutuhan cukup. Tetapi dalam perbedaan pendapatan ini, menunjukkan tidak adanya perbedaan dalam pengasuhan berdasarkan tingkat pendapatan keluarga.

\section{KESIMPULAN}

Dari hasil penelitian dapat disimpulkan bahwa tidak terdapat perbedaan pola pengasuhan anak balita berdasarkan tingkat pendapatan keluarga. Hasil perhitungan presentase pola pengasuhan anak balita berdasarkan tingkat pendapatan tinggi, pendapatan menengah dan pendapatan rendah sebagian besar menerapkan pola pengasuhan yang sama yaitu otoritatif. Artinya, tidak terdapat perbedaan pola pengasuhan anak balita berdasarkan tingkat pendapatan keluarga.

Untuk orang tua yang memiliki anak balita, sebaiknya terapkan pola pengasuhan yang baik untuk anak-anaknya. Karena usia balita merupakan usia dini, usia yang baik untuk perkembangan fisik, kognitif dan psikososial anak. dimana pada masa pengasuhan di usia ini, anak banyak mengingat prilaku baik dan buruk disekitar lingkungan mereka. Orang tua sebagai ujung tombak keberhasilan anak, sebagai guru pertama untuk anak, maka terapkanlah pengasuhan yang baik untuk anakanaknya. Tingkat pendapatan keluarga, bukan lah penyebab berhasil atau tidak nya pengasuhan orang tua terhadap anaknya. Jangan menjadikan anak sebagai objek utama untuk disalahkan apabila keluarga sedang menghadapi krisis ekonomi, dan bagi peneliti lain yang ingin meneliti tentang pola pengasuhan anak balita, sebaiknya memperhatikan factor-faktor lain yang dapat mempengaruhi pola pengasuhan anak balita, karena tidak hanya pendapatan keluarga saja yang dapat mempengaruhinya. 


\section{DAFTAR PUSTAKA}

Adi, R. 2004. Metodologi Penelitian Sosial dan Hukum. Jakarta: Granit.

Agustina. 2008. Pengaruh Pola Asuh Orang Tua Terhadap Disiplin Anak Usia 3-5 tahun. Skripsi. Universitas Negeri Jakarta.

Akdon dan Hadi. 2005. Aplikasi Statistika dan Metode Penelitian untuk Administrasi \& Manajemen. Bandung: Dewa Ruchi.

Arikunto, S. 2008. Dasar-dasar Evaluasi Pendidikan. Jakarta: Bumi Aksara.

Arikunto, S. 2010. Prosedur Penelitian Suatu Pendekatan Praktik. Jakarta: Rineka Cipta.

Bahfen, M. 2011. Pola Pengasuhan Anak Usia Dini Yang Ditinggal Ibunya Bekerja Di Luar Negeri. [tesis]. Jakarta: Program Pascasarjan. Universitas Negeri Jakarta.

Boediono. 1996. Ekonomi Mikro. Yogyakarta: BPFE.

Djaali, \& Muljono, P. 2011. Pengukuran dalam Bidang Pendidikan. Jakarta: PT Grasindo.

Elsyajjaa. 2010. Pengaruh Pola Asuh Orang Tua Terhadap Pembentukan Kepribadian Anak tersedia di http://elsyajjaa.wordpress.com/2010/12/ 19/pengaruh-pola-asuh-orang-tuaterhadappembentukan-kepribadian anak/ http://bps.go.id/menutab.php?tabel=1\&kat=1\&id_subyek=40 http://ilmuandinformasi.blogspot.com/2013/06/teori-pendapatan.html

Ginting, R. 2012. Meningkatkan Kemampuan Komunikasi Interpersonal Melalui Bermain Kreatif pada Anak Usia 3-5 tahun. [tesis]. Jakarta: Program Pascasarjana. Universitas Negeri Jakarta.

Gunarsa, S. 2003. Dasar dan Teori Perkembangan Anak. Jakarta: Gunung Mulia.

Haryanti. 2004. Penerapan Disiplin Oleh orang Tua yang Pernah Mengalami Kekerasan di Masa Kecil. Depok, Jurnal Psikologi, Universitas Indonesia.

Hasan, I. 2004. Analisis Data Penelitian dengan Statistik. Jakarta: Bumi Aksara Hildayani. 2011. Psikologi Perkembangan Anak. Jakarta: Universitas Terbuka.

Indriastuti, D. 2001. Sikap Konformitas Remaja Ditinjau dari Persepsi Terhadap Status Sosial Ekonomi Orangtua. eprints.unika.ac.id/12419/1/94.40.1835_D hanar_Indriastuti.pdf

Jalal, F. 2005. Arah Kebijakan Nasional Pendidikan Anak Usia Dini (jalur pendidikan Non Formal), Depdiknas. Jakarta

Kadariyah. 1981. Analisa Pendapatan Nasional. Jakarta: Bima Aksara.

Kasina, Ahmad \& Hikma, 2005. Perlindungan dan Pengasuhan Anak Usia Dini. Jakarta: Dirjen Pendidikan Tinggi Depdiknas

Lidyasari, A. 2010. Pola Asuh Otoritatif sebagai Sarana Pembentukan Karakter Anak dalam Setting Keluarga. [skripsi]. Jakarta: Universitas Negeri Jakarta

Mulyanto Sumardi dan Hans Dieter-Evers. 1982. Kemiskinan dan Kebutuhan Pokok. Jakarta: Rajawali.

Muryono, 2009. Empati, Penalaran Moral, dan Pola Asuh. Yogyakarta: Gala Ilmu Semesta.

Paputungan, H. 2009. Pengaruh Lingkungan Pengasuhan, Pendapatan Keluarga, dan Status Gizi Terhadap Perkembangan Psikomotor Anak Usia Batita. [Disertasi]. Jakarta: Universitas Negeri Jakarta.

Rosdianah. 2009. Hubungan Antara Pola Asuh Orang Tua dan Konsep Diri dengan Keterampilan Sosial. [tesis]. Jakarta: Program Pascasarjana, Universitas Negeri Jakarta.

Santrock, J.W. 2002. Life-S pan Development. (Achmad Chuisari, Jakarta: Erlangga)

Santrock, J.W. 2011. Masa Perkembangan Anak. Jakarta: Salemba Humanika.

Sardin. 2012. Pengaruh Persepsi Orang Tua Tentang Anak, Status Sosial Ekonomi Keluarga, Keterlibatan Dalam Program Taman Kanak-kanak, dan Pola Asuh Mendidik Terhadap Kesiapan Bersekolah Anak Taman Kanak-Kanak. [disertasi]. Jakarta: Program Pascasarjana.Universitas Negeri Jakarta

Semiawan, C. 2008. Penerapan Pembelajaran Pada Anak. Jakarta: PT. Indeks. 
Setianingsih, D. 2007. Perbedaan Kedisiplinan Belajar Siswa Ditinjau dari Pola Asuh Orang tua. Surakarta: Fakultas Psikologi Universitas Muhammadiyah.

Singarimbun, M. 2008. Metode Penelitian Survai. Jakarta: LP3ES

Siswanta, L. 2008. Kontribusi Home Industry dalam MeningkatkanKesejahteraan Sosial Ekonomi Keluarga (Studi Kasus di Desa Wukirsari, Imogiri). Akmenika UPY, Volume 2:http://upy.ac.id/ekonomi/files/Kontribusi home industry dalam meningkatkan kesejahteraan sosial ekonomi keluarga (studi kasus di desa wukirsari, imogiri) (lilik siswanta).

Soedarmono. 2000. Kontribusi Motivasi Belajar Sejarah dan Latar Belakang Sosial Ekonomi Keluarga Terhadap Pemahaman Nilai-Nilai Kepahlawanan. [tesis]. Jakarta: Program Pascasarjan. Universitas Negeri Jakarta.

Sugiyono. 2008. Metode penelitian Kuantitatif, Kualitatif dan R\&D. Bandung: Alfabeta

Sugiyono. 2010. Metode Penelitian Bisnis. Bandung. Alfabeta

Suherman, E. 2001. Evaluasi Proses Dan Hasil Belajar Matematika. Jakarta : Universitas Terbuka

Tarmudji, T. 2002. Hubungan Pola Asuh Orang Tua Dengan Agresivitas Remaja, J urnal Pendidikan Dan Kebudayaan, Badan Penelitian Dan Pengembangan. (J akarta: Depdiknas)

Yusuf, S. 2011. Psikologi Perkembangan Anak dan Remaja. PT Remaja Rosdakarya. Bandung. 